\title{
Incidence of HIV Cases and Associated Factors in The Northeast Region of
}

\section{Brazil}

\section{Roberta Pinheiro de Souza ${ }^{1}$ | Andressa Cristielle Santos Campos ${ }^{1}$ | Ana Maria Fernandes Menezes $^{1}$ | Wanessa de Cássia Martins Antunes de Melo*}

\section{*Correspondence: Wanessa de Cássia Martins Antunes de Melo}

Address: ${ }^{1}$ Graduated in the Biomedicine Course, University Center FG - UNIFG; ${ }^{2}$ Department of Biomedicine, University Center FG - UNIFG; ${ }^{2}$ WCMA, Address: Laboratory of Bioelectric, State Research Institute, Department of Functional Materials and Electronics, Center for Physical Sciences and Technology, Vilnius, Lithuania

e-mail $\bowtie$ : wanessa.melo@ftmc.lt

Received: 10 May 2021; Accepted: 29 June 2021

Copyright: (C) 2021 Pinheiro de Souza R. This is an open-access article distributed under the terms of the Creative Commons Attribution License, which permits unrestricted use, distribution, and reproduction in any medium, provided that the original work is properly cited.

\section{ABSTRACT}

BACKGROUND: The Acquired Immunodeficiency Syndrome (AIDS) is caused by the human immunodeficiency virus (HIV) and has been widely discussed by generating a pandemic and a global public health problem, being difficult to control nowadays. The first cases in Brazil started in 1980 and, reached 882,810 cases of HIV/AIDS in 2017, totaling an average of 40 thousand new cases of AIDS in the last five years, centralized in the Southeast and South regions, reaching $52.3 \%$ and $20.1 \%$ of cases, respectively. In the Northeast, between 2007 and 2017, 30,297 (15.6\%) were notified, being the region in the 3rd position when compared to other regions of Brazil. Thus, it was analyze the socio-demographic profile of subjects positive for HIV/AIDS in the Northeast region of Brazil. Materials and Methods: A quantitative, epidemiological, descriptive, retrospective analysis study was carried out, which assessed the incidence of HIV carriers in northeastern of Brazil. The data were carrying out according to the DATASUS (Departamento de informática Sistema Único de Saúde do Brasil) and the parameters investigated were the ones available into this public health system (gender, race, education, age, and exposure category). In addition, all parameters were analyzed using Bioestat 5.0 software and applied Pearson's chisquare. Results: There was predominance in male individuals with $65 \%$ of confirmed cases. In terms of age group, the most affected group is between 40 and 49 years old, being expressed in $23.6 \%$ of cases. When assessing the education of the carriers of the virus, people with incomplete primary education occupied $42.9 \%$ of infected. Conclusions: HIV/AIDS infection, even today, constitutes a regional public health problem in Brazil.

Keywords: HIV/AIDS, Northeast, Epidemiological Profile

\section{Introduction}

The Acquired Immunodeficiency Syndrome (AIDS) is caused by the human immunodeficiency virus (HIV) and has been widely discussed by generating a pandemic and a global public health problem, being difficult to control nowadays (Ferraz and Paiva, 2015; Guedes et al., 2017). 
HIV is a retrovirus of the Lentivirus subgroup of the Retroviridae family, has an icosahedral shape that infects humans. It belongs to two groups, cytopathic and non-oncogenic retroviruses. Its morphology is spherical, has a diameter of 100 to $120 \mathrm{~nm}$, and a capsule containing a lipid membrane in which it contains glycoproteins gp120 and gp41. The virus nucleus has two molecules of genomic RNA and has the enzyme reverse transcriptase, which may lead the carrier to develop the Acquired Immunodeficiency Syndrome (AIDS) as a consequence (Silva, 2008; Oliveira, 2015).

Currently, there are two types of viruses that cause AIDS: HIV-1 and HIV-2. HIV-1 circulates in the world with a high degree of genetic diversity, which can influence biological aspects such as infectivity, transmissibility, and immunogenicity, in addition to presenting a high rate of replication. HIV-2 is mainly present in the African continent and, unlike type 1, denotes less pathogenicity (Paula, 2015; Costa, 2017).

The propagation of this infection happens in different ways, the most common through unprotected sex - both heterosexual and homosexual; blood transfusions and their derivatives, both contaminated; use of injectable drugs with the sharing of contaminated syringes; transplantation transmission; contaminated mother-to-baby during pregnancy, birth and breastfeeding and tattoos (Romano, 2016; Guedes et al., 2017; Pereira et al., 2017).

In 2016, 1.8 million subjects tested positive for HIV in the world, increasing the epidemiological scenario to 36.7 million people infected with HIV/AIDS. At the same time that a significant increase of infection is observed, it was reported that, since the year 2010, with the implementation of prevention and treatment programs, there has been a decline of $16 \%$ in cases of transmission (Freitas et al., 2018).

In Brazil, the first cases of HIV/AIDS started in 1980 and, reached 882,810 cases of HIV/AIDS in 2017, totaling an average of 40 thousand new cases of AIDS in the last five years, centralized in the Southeast and South regions, reaching $52.3 \%$ and $20.1 \%$ of cases, respectively. In the Northeast, between 2007 and 2017, 30,297 (15.6\%) were notified, being the region in the 3rd position when compared to other regions of Brazil (Unaids, 2017).

Analyzing the exposure category in relation to the situation of the greatest vulnerability is observed that the HIV prevalence rates were 5 - 5.9\% among drug users, $10.5 \%$ among men who have sex with men (MSM) e 4.9\% among female sex workers (Oliveira, 2017).

In relation to the treatment of this illness, there is the use of antivirals drugs since 1996 which are provided by a health-free system in Brazil (Sistema Único de Saúde - SUS), allowing a prolonged 
survival in many cases. However, the accessibility and the acceptability still remain as obstacles because one of the main hurdlings between subjects positive for HIV is associated with the treatment and the prejudice faced by them since the carrier's life will be profoundly transformed in several aspects after knowing about the real condition of an HIV seropositive (Vielmo et al., 2014; Romano, 2016).

The quick evolution to the AIDS is associated with the delay in diagnosis and early treatment, due to the prejudice faced, mainly, by homosexual groups (Unaids, 2017).

Is known that antiretroviral drugs have provided an increase in the survival of HIV carriers and that they undergo risky behavior, thus increasing the chances of contracting other sexually transmitted infections (STIs) (Okuno, 2014; Jesus et al., 2017).

Given the information above, this project aim is demonstrate and analyze the epidemiological profile of the HIV seropositive population in the Northeast region of Brazil.

\section{Materials and Methods}

A quantitative, epidemiological, descriptive, retrospective analysis study was carried out which analyzed the incidence of HIV carriers in the Northeast region of Brazil. This region contains 73,341 residents, following the Instituto Brasileiro de Geografia e Estatística (IBGE), being the second most populated region in Brazil.

All the HIV cases confirmed in the Northeast region between 2007 and 2017, they were analyzed according to the available data from DATASUS, which is an agency of the Secretariat for Strategic and Participatory Management of the Ministry of Health, with the responsibility of collecting, processing and disseminating information on health. The population group to be investigated (inclusion criteria) was selected according to the ones that were obtainable from DATASUS: gender, race, education, age, and exposure category. The exclusion criteria were the ones outside of the period and the region of the study.

The data were collected considering the confirmed cases according the epidemiological surveillance of the states and are available openly by Sistema de Informação de Agravos de Notificação, do Ministério da Saúde, TAB NET and Vigilância Epidemiológica. The data has open access and does not have the identification of the carriers of the disease.

The data were organized in Bioestat 5.0 software, for analysis statistics, in which Pearson's chisquare test was applied, with a significance level of $5 \%(p<0.05)$. 
As this is a secondary data survey and does not directly involve human beings, this study was not submitted to the Research Ethics Committee.

\section{Results and Discussion}

According the Sistema de Agravo e Notificações (SINAN), were recorded 57,048 (100\%) HIV infection cases in the Northeast region of Brazil between 2007 and 2017. These records are powered by the notification and investigation of cases of diseases and conditions that appear on the national list of compulsory notification diseases. Medical files are the ones that update the national list, showing the positive diagnostic for the HIV only after immune window.



Figure 1: HIV cases reported per year in Northeast region, Brazil, 2018

In relation to the predominance of these cases in Northeast state, is possible to note that between 2007 and 2017, Pernambuco, Bahia, Ceara, and Maranhão states showed the greatest numbers of HIV cases notified. While Sergipe and Piauí states showed fewer notified cases.

The data demonstrated, from 2007 to 2013, that the HIV/AIDS cases increased gradually, being responsible for $67.4 \%$ of all percentage of cases in the study period. These dates corroborate with a study developed by Cruz (2016) in Cariri city in Ceará state that shows that in the same period there was a significant increase in HIV cases.

On the other side, was observed a reduction in HIV cases from 2014 to 2017. However, this result confronts the study developed by Costa (2015), which demonstrated, in 2014, a sharp increase in HIV cases in the study microregion. This year was included compulsory notifications of HIV cases and not only AIDS, as in notifications from previous years.

Considering all years of the study, was observed a predominance of confirmed cases in the male gender (65\%) while $34.5 \%$ of cases happened in the female gender. This fact can occur due to the 
homosexual and bisexual practice of several men that make them more prone to acquire the infection, since the non-use of condoms during sexual practices, whether vaginal, anal or oral, can cause lesions in the mucous membranes that line these regions during the practice and facilitate contagion through semen or vaginal/urethral fluids during the act (UNAIDS, 2017). It is noted that these study data corroborated with a study developed by Soares and Morais (2014) realized in Vitória da Conquista city, localized in the Southwest of Bahia, one of the states included in this research data.

Another fact got that this study related to sex cases, is the gradual increase of HIV cases in women over the years and in all capital studied. Moura and Faria (2017) argue in their study that the number of women HIV infected happens quickly and the main infection category was heterosexual. Once again unprotected sex leads as the main form of transmission. This finding corroborates with the study of Pereira et al. (2014) who cite the phenomena of feminization and heterosexualization of AIDS, since many women trust their partner, while others find it difficult to convince the partner to use condoms in relationships because for him this fact can demonstrate mistrust. According to Paes, et al. (2017), in this sense, women can favor vertical transmission, and also the contamination of women of reproductive age is common since they are more sexually active.

Considering the age group, the most affected include individuals with 40 to 49 years old, representing about $22.6 \%$ of cases, which brings a medium of $1.4 \%$ of people with HIV infection aged 40 to 49 years, in the states of the Northeast region of Brazil. With regard to the age groups included between 20 and 39 years, there is a percentage of 59.3\% of cases, thus having more than half of all cases. According to the research developed by Silva et al. (2014), there was an increase of positive results in groups aged 20 to 39 in 2014, showing a percentage of 60\% of cases. Moura and Faria (2017) pointed out the increase in the number of cases in this group age too (Table 1).

Table 1: Notified cases of HIV/AIDS by age group in the Northeast Region of Brazil, Brazil, 2018

\begin{tabular}{|c|c|c|c|c|c|}
\hline Demographic characteristics & $\mathbf{N}$ & $\%$ & DF & $X^{2}$ & $\mathbf{P}^{*}$ \\
\hline \multicolumn{6}{|l|}{ AGE GROUP } \\
\hline$<5$ years & 646 & $1,132 \%$ & 8 & 324.022 & \multirow{10}{*}{$<0.0001$} \\
\hline $5-12$ & 357 & $0,625 \%$ & 8 & 110.218 & \\
\hline $13-19$ & 1351 & $2,368 \%$ & 8 & 449.087 & \\
\hline $20-24$ & 5263 & $9,225 \%$ & 8 & $1,907.308$ & \\
\hline $25-29$ & 8879 & $15,564 \%$ & 8 & $3,104.138$ & \\
\hline $30-34$ & 10441 & $18,302 \%$ & 8 & $4,009.96$ & \\
\hline $35-39$ & 9232 & $16,182 \%$ & 8 & $3,394.772$ & \\
\hline $40-49$ & 12936 & $22,675 \%$ & 8 & $4,555.678$ & \\
\hline $50-59$ & 5734 & $10,051 \%$ & 8 & $2,236.60$ & \\
\hline $60+$ years & 2209 & $3,872 \%$ & 8 & 721.354 & \\
\hline
\end{tabular}

$\mathrm{N}$ : number of subjects, \% percentage, DF: degrees of freedom, $\mathrm{X}^{2}$ : Chi-square test statistic, $\mathrm{P}^{*}$ : significant $\mathrm{p}$-value. SOURCE: Ministério da Saúde/SVS - Sistema de Informação de Agravos de Notificação - Sinan 
Garcia and Souza (2010) developed research in order to verify the peoples' knowledge, of different ages, about AIDS and found that the knowledge degree about this depends on the age when it is directly related to education levels. They noticed that the higher is the age and education level, the lower is the number of people infected with HIV. However, is important to highlight that even people with a high level of education and, therefore, easier access to information, are prone to contracting this disease as well as being a carrier of it, but in a number generally lower than those with less instruction.

We found a similar result with the study of Garcia and Souza (2010). When we analyze the virus carrier scholarity, we showed, in general, that people with incomplete High School (5 $5^{\text {th- }} 8^{\text {th }}$ grade) occupied $42.9 \%$ of infected people. Following this, 20.2\% of cases reported having completed High School. On the other side, an interesting fact was that unlettered people occupied a percentage of only $6.4 \%$ of total cases (Table 2). Our study corroborated with the results of Ferreira, Souza and Júnior (2015) which showed a less percentage of individuals with the virus in the unlettered group.

The studies of Menezes, et al. (2018) and Paes, et al. (2017) too confirmed the results reported in this research, since they demonstrated that the vast majority of HIV cases had incomplete basic education. It can demonstrate that low degrees of scholarity, suggesting a possible relationship with the population impoverishment, are linked with the higher HIV infection risk, maybe, due to the difficulty of information access or due to fakes news and less access to means of prevention. As confirmed in another study, the spread of HIV is concentrated in the poorest strata of society and with a lower educational level (Costa, 2011).

Table 2: Notified cases of HIV/AIDS by scholarity in the Northeast Region of Brazil, Brazil, 2018

\begin{tabular}{|c|c|c|c|c|c|}
\hline Demographic characteristics & $\mathbf{N}$ & $\%$ & DF & $X^{2}$ & $\mathbf{P}^{*}$ \\
\hline \multicolumn{5}{|l|}{ SCHOLARITY } & \multirow{9}{*}{$<0.0001$} \\
\hline Unlettered & 2706 & $6.417 \%$ & 8 & 666.386 & \\
\hline Incomplete basic & 18122 & $42.975 \%$ & 26 & $10,973.979$ & \\
\hline Basic & 4453 & $10.560 \%$ & 8 & $1,172.671$ & \\
\hline Incomplete High School & 3187 & $7.557 \%$ & 8 & $1,332.612$ & \\
\hline High school & 8536 & $20.242 \%$ & 8 & $3,496.072$ & \\
\hline Incomplete College & 1658 & $3.93 \%$ & 8 & 526.568 & \\
\hline College & 2745 & $6.509 \%$ & 8 & 704.623 & \\
\hline Not applicable & 761 & $1.804 \%$ & 8 & 358.938 & \\
\hline
\end{tabular}

$\mathrm{N}$ : number of subjects, \% percentage, DF: degrees of freedom, $\mathrm{X}^{2}$ : chi-square test statistic, $\mathrm{P}^{*}$ : significant $\mathrm{p}$-value. SOURCE: Ministério da Saúde/SVS - Sistema de Informação de Agravos de Notificação - Sinan.

Another aspect analyzed in this study was the race of cases studied (Table 3). We observed the dominance of mixed race, with $67.4 \%$ of all recorded cases, followed by white people with $14.7 \%$ of cases. According to Silva (2018), the mixed was the predominant color in subjects positive for HIV in the study region and, the white color occupied the second percentual of cases in the race question. Sousa 
(2014) showed the same result in relation to mixed-race in Bahia state. Paes, et al. (2017) too obtained similar results, with the greatest case percentage occurred in mixed individuals. It can be explained by local characteristics and by this race be the most prevalent in Brazil and in the study region, also having a strong bond with the indigenous ethnic group.

Table 3: Notified cases of HIV/AIDS by race in the Northeast Region of Brazil, Brazil, 2018

\begin{tabular}{|l|l|l|l|l|l|}
\hline Demographic characteristics & $\mathbf{N}$ & $\mathbf{\%}$ & DF & $\mathbf{X}^{\mathbf{2}}$ & \multicolumn{2}{|c|}{ P $^{*}$} \\
\hline RACE & & & & & \\
\hline White & 8376 & $14.682 \%$ & 8 & $4,062.855$ & \\
\hline Black & 5428 & $9.514 \%$ & 8 & $6,704.123$ & $<0.0001$ \\
\hline Yellow/Asian & 203 & $0.355 \%$ & 8 & 146.404 & \\
\hline Mixed & 38455 & $67.408 \%$ & 8 & $11,778.865$ & $<0.0001$ \\
\hline Indigenous & 147 & $0.257 \%$ & 8 & 177.551 & $<0.0001$ \\
\hline Undeclared & 4439 & $7.781 \%$ & 8 & $4,654.514$ & \\
\hline
\end{tabular}

$\mathrm{N}$ : number of subjects, \% percentage, DF: degrees of freedom, $\mathrm{X}^{2}$ : chi-square test statistic, $\mathrm{P}^{*}$ : significant $\mathrm{p}$-value. SORCE: Ministério da Saúde/SVS - Sistema de Informação de Agravos de Notificação - Sinan.

With regard to the exposure category, heterosexuals lead the number of cases in all years (20072017), exceeding half of all those confirmed, with 55.6\% of studied cases (Table 4). What changes a lot when compared with the period of 1980 until current the days. In 80 decade, the incidence of HIV was most restrict and directed to the homosexual category, however, actually, is possible to note the increase of cases and greater incidences and prevalence in heterosexual patients, being classified as heterosexualization of the disease, favoring infection of both sexes, not being restricted to just one category (Brito et al., 2000).

Table 4: Notified cases of HIV/AIDS by exposure category in the Northeast Region of Brazil, Brazil, 2018

\begin{tabular}{|c|c|c|c|c|c|}
\hline Demographic characteristics & $\mathbf{N}$ & $\%$ & DF & $\mathrm{X}^{2}$ & P* \\
\hline \multicolumn{5}{|l|}{ EXPOSURE CATEGORY } & \multirow{8}{*}{$<0.0001$} \\
\hline Homosexual & 8834 & $15.485 \%$ & 8 & $3,458.05$ & \\
\hline Bisexual & 3185 & $5.583 \%$ & 8 & 886.507 & \\
\hline Heterosexual & 31745 & $55.646 \%$ & 8 & $12,180.138$ & \\
\hline IDU* & 919 & $1.610 \%$ & 8 & $1,182.446$ & \\
\hline Hemophilic & 14 & $0.024 \%$ & & & \\
\hline Vertical Transmission & 1360 & $2.383 \%$ & 8 & 628.497 & \\
\hline Undeclared & 10982 & $19.250 \%$ & 8 & $7,462.257$ & \\
\hline
\end{tabular}

$\mathrm{N}$ : number of subjects, \% percentage, DF: degrees of freedom, $\mathrm{X}^{2}$ : chi-square test statistic, $\mathrm{P}^{*}$ : significant $\mathrm{p}$ value.* Injecting Drug Users. SOURCE: Ministério da Saúde/SVS - Sistema de Informação de Agravos de Notificação -Sinan.

When analyzing HIV infections in the different states of the Northeast region, we highlight Pernambuco and Bahia states, respectively. Together, these states are responsible for more them 50\% of total HIV infections in all region. According to França, et al. (2015), the annual medium of HIV/AIDS new cases by the state was $30.8 \%$ of people, however when compared with some Northeast states, as 
Bahia, Pernambuco, Ceará, and Maranhão this value exceed by almost 100\%, seeing a predominance between these two regions. Some factors as interiorization, deficiency in the state for prevention practices and incentives, and low remuneration can be taken into account for such an increase.

The HIV virus has the ability to invade lymphocytes-T through receptors-CD4, after the invasion the macrophages are activated and migrate into systemic circulation to perform phagocytosis, this process causes a sudden drop in lymphocytes-CD4 leading patients to lymphopenia. The virus leaves the autoimmune system debilitated, which makes the viral charge high due the multiplication of the virus (Sehnem et al., 2020).

After data analysis and discussion, is possible to realize that the behind data showed that in the period between 2007 to 2017, people of mixed race, man gender, and between 20 until 49 ages, are more likely to be carriers of the HIV virus in the Northeast region of Brazil, especially in the states of Pernambuco and Bahia. However, is important to highlight that this study it is reporting a restrict period of time (10 years) and in a specific localization (Northeast region of Brazil), being a limitation of it.

\section{Conclusions}

The results about the epidemiological panorama of HIV/AIDS in the Northeast region showed that the most part of the population with HIV/AIDS in the region is composed of young males with low education level (pauperization phenomenon). Other factors also exposed were associated with the greater involvement of male homosexual or bisexual individuals. In addition, was observed the tendency to alteration of the HIV epidemiological profile, since was showed an increase in the heterosexual female population, in comparison with the last decade, knowing as feminization.

As future perspective, the authors suggest that this article may contribute to outline an epidemiological profile of HIV/AIDS around the region of the study. Thus, showing for the society the needed to implement preventive measures and campaigns, guiding them about the real problems that an individual may present if was infected by HIV virus.

Acknowledgments: The author's sincere thanks for the support from University Center FG - UNIFG.

Conflict of Interest: The authors declare that the research was conducted in the absence of any commercial or financial relationships that could be construed as a potential conflict of interest. 


\section{References}

Brito AM, Castilho EA, Szwarceald CL. AIDS e infecção pelo HIV no Brasil: uma epidemia multifacetada. Rev Soc Bras Med Trop 2000; 34: 207-217.

Costa MC, Santos BC, de Souza KE, de Almeida Cruz NL, Santana MC, do Nascimento OC. HIV/AIDS e Sífilis em Gestantes Adolescentes e Adultos Jovens: Fatores de Exposição e Risco dos Atendimentos de um Programa em DST/HIV/AIDS na Rede Pública de Saúde/SUS, Bahia, Brasil. Revista Baiana de Saúde Pública 2011; 35: 179-185.

Costa PR. Avaliação do perfil de ativação de células T nas fases recente e estabelecida de infecções por subtipos C e nãoC do vírus HIV-1, PhD thesis, Faculdade de Medicina da Universidade de São Paulo, São Paulo; 2017. 155 p.

Costa SSR. Perfil socioeconômico e epidemiológico dos indivíduos que vivem com HIV/AIDS notificados no município de Santo Antônio de Jesus - BA de 2007 a 2014, Graduate thesis, Universidade Federal do Recôncavo da Bahia, Santo Antônio de Jesus; 2015, 83 p.

Cruz KO. Perfil epidemiológico de HIV/AIDS na região metropolitana do Cariri cearense: estudo comparativo. Revista eciência 2016; 4:53-62.

Ferraz D and Paiva V. Sex, human rights and AIDS: an analysis of new technologies for hiv prevention in the brazilian context. Revista Brasileira de Epidemiologia 2015; 18: 89-103.

Ferreira TCR, Souza APC, Júnior RSR. Perfil clínico e epidemiológico dos portadores do HIV/AIDS com coinfecção de uma unidade de referência especializada em doenças infecciosas parasitárias especiais. Revista da Universidade Vale do Rio Verde 2015; 13: 419-431.

França CS, Santos TTM, Cavalcante GA, Duarte ENC, Silva EO. Prevalência de HIV/AIDS em idosos no Nordeste brasileiro: um estudo epidemiológico. Anais CIEH; 2015; Curitiba, Brazil; 2015, P. 1-6.

Freitas JP, Sousa LRM, Cruz MCMA, Caldeiras NMVP, Gir E. Terapia com antirretrovirais: grau de adesão e a percepção dos indivíduos com HIV/ Aids. Revista Acta Paul Enferm 2018; 31: 327-333.

Garcia S, Souza FM. Vulnerabilidades ao HIV/AIDS no contexto brasileiro: iniquidades de gênero, raça e geração. Revista Saúde Soc 2010; 19: 9-20.

Guedes RB, Fukuda MTH, Silva K, Dornelas R, Domenis DR, Takayanagui OM. Linguagem oral e escrita de crianças soropositivas para o HIV: um acompanhamento longitudinal. Audiolcommun res 2017; 22: 1-6.

Jesus GJD, Oliveira LB, Caliari JS, Queiroz AAFL, Girl E, Reis RK. Dificuldades do viver com HIV/AIDS: Entraves na qualidade de vida. Acta Paulista de Enfermagem 2017; 30: 301-307.

Menezes AMF, Almeida KT, Nascimento AKA, Dias GCM, Nascimento JC. Perfil Epidemiológico das pessoas soropositivas para HIV/AIDS. Revenferm UFPE online 2018; 12: 1225-1232.

Moura JP, Faria MR. Caracterização e perfil epidemiológico das pessoas que vivem com hiv/aids. Revista de Enfermagem Ufpe on Line 2017; 11: 5214-5218.

Okuno MFP, Gomes AC, Meazzini L, Júnior GS, Domingos BJ, Angélica GSB. Qualidade de vida de pacientes idosos vivendo com HIV/AIDS. Cad. Saúde Pública 2014; 30: 1551-1559.

Oliveira ÉF. Avaliação da frequência de marcadores da ativação imune em pacientes infectados pelo HIV-1 com diferentes níveis de restauração da imunidade, MSc thesis, Universidade Federal da Bahia, Salvador; 2015.52 p. 
Oliveira UR. Avaliação epidemiológica e sorológica em pacientes portadores de HIV em ambulatório de referência. Graduate thesis, Faculdade de Medicina da Bahia (FMB), Universidade Federal da Bahia (UFBA), Salvador; 2017, 56 p.

Paes ALV, Gomes HG, Ribeiro ARS, Lima MMB, Araújo BB, Smith NA. Perfil epidemiológico de gestantes com HIV acompanhadas em um serviço de assistência especializada em Belém-PA. Revista Interdisciplinar 2017; 10: 100-109.

Paula DP. Prevalência da co-infecção em pacientes HIV soropositivos com HTLV 1 e 2 em dois centros de referência de Goiânia-GO. MSc thesis, Pontifícia Universidade Católica de Goiás, Goiânia; 2015. 85 p.

Pereira BS, Costa MCO, Amaral MTR, Costa HS, Silva CAL, Sampaio VS. Fatores associados à infecção pelo HIV/AIDS entre adolescentes e adultos jovens matriculados em Centro de Testagem e Aconselhamento no Estado da Bahia, Brasil. Ciência \& Saúde Coletiva 2014; 19: 747-758.

Pereira MG, Silva MG, Gontijo EE, Costa MA, Silveira LM, Marroni MA. Perfil sociodemográfico e clínico de pacientes adultos HIV (+), atendidos na Policlínica municipal de Gurupi-TO. Revista Cereus 2017, 9: 111-222.

Romano LGA. Perspectiva da saúde mental no serviço de assistência especializada para pessoas vivendo com HIV/AIDS. Graduate thesis, Universidade Federal do Rio Grande do Sul, Porto Alegre; 2016, 43 p.

Sehnem G, Silva LGC, Crespo CB, Merigo GK, Bofill MAM e Rezer JFP. Aspectos clinico-epidemiológicos de portadores de hiv na fronteira oeste do Rio Grande do Sul, Rio Grande do Sul. Anais Do Salão Internacional De Ensino, Pesquisa E Extensão 2020; 10 .

Silva CM, Alves RS, Santos TS, Bragagnollo GR, Tavares CM, Santos. Panorama epidemiológico do HIV/aids em gestantes de um estado do Nordeste brasileiro. Revista Brasileira de Enfermagem 2018; 71: 613-621.

Silva JAG I, Brito AM, Silva CAL Dourado. Fatores associados à não adesão aos antirretrovirais em adultos com AIDS nos seis primeiros meses da terapia em Salvador, Bahia, Brasil. Cad Saúde Pública 2015; 31: 1188-1198.

Silva KPBD, Tomasi LG, Elias RM, Silva LM. Perfil epidemiológico da infecção pelo vírus HIV na cidade de Várzea Grande - MT, no período de 2011 a 2014. Revista CONNECTIONLINE 2014; 15: 57-69.

Silva MM. Polimorfismo da região do fator de Necrose Tumoral (TNF) na síndrome da lipodistrofia associada à terapia antirretroviral em portadores do HIV-1. MSc thesis, Escola de Enfermagem de Ribeirão Preto, Ribeirão Preto; 2008.155 p.

Soares FNS, Morais MTM. Perfil epidemiológico e sócio demográfico dos pacientes vivendo com HIV/AIDS cadastrados no município de Vitória da Conquista/BA. Rev Saúde Com 2014; 10: 54-63.

Sousa AR. Distribuição espaço-temporal da AIDS, na Bahia, período 2002 a 2012. MSc thesis, Instituto de Saúde Coletiva, Universidade Federal da Bahia, Salvador; 2014, 83 p.

UNAIDS BRASIL. Relatório do UNAIDS é 'ponto de referência vital' para monitorar progressos na resposta ao HIV. [cited 13 Nov 2017] Available from: https://unaids.org.br/2017/07/relatorio-unaids-e-ponto-de-referencia-vital-para-monitorarprogressos-na-resposta-ao-hiv-diz-lancet/.

Vielmo L. Atenção farmacêutica na fase inicial de tratamento da AIDS como fator importante na adesão aos antirretrovirais. Revista Brasileira de Farmácia 2014; 95: 617-635. 